\title{
Short communication: Associations of feeding behavior and milk production in dairy cows
}

\author{
C. Johnston and T. J. DeVries ${ }^{1}$ \\ Department of Animal Biosciences, University of Guelph, Guelph, Ontario, N1G 2W1, Canada
}

\begin{abstract}
Identification of the associations of cow feeding behavior with productivity is important for supporting recommendations of strategies that optimize milk yield and composition. The objective of this study was to identify associations between measures of feeding behavior and milk production using data collated from studies of the feeding behavior of lactating dairy cows. A database containing behavior and production data for 132 dairy cow-week observations (mean of $7 \mathrm{~d}$ of consecutive data per cow) was assembled from 5 studies. Cows averaged (mean \pm standard deviation) 1.8 \pm 0.9 lactations, $108.4 \pm 42.7 \mathrm{~d}$ in milk, and $654.6 \pm$ $71.4 \mathrm{~kg}$ of body weight during each observation week. Production data included dry matter intake $(27.0 \pm$ $3.1 \mathrm{~kg} / \mathrm{d})$, milk yield $(43.0 \pm 7.0 \mathrm{~kg} / \mathrm{d})$, milk fat content $(3.60 \pm 0.49 \%)$, and milk protein content $(3.05 \pm$ $0.25 \%)$. Behavioral data included feeding time $(230.4 \pm$ $35.5 \mathrm{~min} / \mathrm{d})$, feeding rate $(0.13 \pm 0.03 \mathrm{~kg} / \mathrm{min})$, meal frequency $(9.0 \pm 2.0$ meals/d), meal size $(3.2 \pm 0.9$ $\mathrm{kg} / \mathrm{meal})$, daily mealtime $(279.6 \pm 51.7 \mathrm{~min} / \mathrm{d})$, and rumination time $(516.0 \pm 90.7 \mathrm{~min} / \mathrm{d})$. Data were analyzed in multivariable mixed-effect regression models to identify which behavioral variables, when accounting for other cow-level factors (days in milk, parity, and body weight) and dietary characteristics (forage level, nutrient content, and particle distribution), were associated with measures of production. Dry matter intake was associated with feeding time $(+0.02 \mathrm{~kg} / \mathrm{min})$ and tended to be associated with rumination time $(+0.003$ $\mathrm{kg} / \mathrm{min})$ and meal frequency $(+0.2 \mathrm{~kg} / \mathrm{meal})$. Similarly, milk yield was associated with feeding time $(+0.03 \mathrm{~kg} /$ $\mathrm{min})$ and rumination time $(+0.02 \mathrm{~kg} / \mathrm{min})$, and tended to be associated with meal frequency $(+0.3 \mathrm{~kg} / \mathrm{meal})$. Milk fat yield was associated with meal frequency $(+0.02 \mathrm{~kg} / \mathrm{meal})$. Overall, our results suggest that milk yield and component production may be improved in
\end{abstract}

Received August 25, 2017.

Accepted December 10, 2017.

${ }^{1}$ Corresponding author: tdevries@uoguelph.ca situations where cows are able to increase their time spent feeding, in more frequent meals, and time spent ruminating.

Key words: feeding behavior, production, rumination

\section{Short Communication}

Milk production, composition, and efficiency can be affected by breed, stage in lactation, age, nutrition, and management strategies (NRC, 2001). Behavior patterns of dairy cattle, such as resting, ruminating, and eating, may also have an effect on these productive outcomes (Grant and Albright, 1995). It is well established that milk production is largely driven by the amount of nutrients consumed, that is, total DMI (Veerkamp, 1998). Dry matter intake is largely a function of feeding behavior, affected by changes in meal size, duration, and frequency, as well as feeding time and rate (Nielsen, 1999). Changes in DMI are linked to concomitant changes in different aspects of feeding behavior (Nielsen, 1999). Feeding behavior may not only affect DMI and subsequent production (Dado and Allen, 1994), but also affect the rumen environment. For example, consuming large meals quickly may cause large postprandial drops in rumen $\mathrm{pH}$ (Allen, 1997); alternatively, consuming more frequent, smaller meals, in a more consistent pattern across the day may stabilize rumen conditions, reducing risk of SARA and improving milk fat production (Krause and Oetzel, 2006; DeVries and Chevaux, 2014). Further, greater time spent eating and ruminating per unit of feed consumed has been associated with improved fiber digestibility in Jersey cows (Aikman et al., 2008).

The body of literature on the effect of housing, nutrition, and management strategies on dairy cow feeding behavior is continually increasing. Identification of the associations of cow feeding behavior with productivity is important for supporting recommendations of strategies that optimize milk composition and yield. Thus, the objective of this study was to identify associations between measures of feeding behavior and milk production using data collated from studies of the feeding behavior of lactating dairy cows. 
A database containing behavior and production data for 132 dairy cow-week observations was assembled from 5 studies conducted at the University of Guelph, Kemptville Campus Dairy Education and Innovation Center (Kemptville, Ontario, Canada). In all studies, cows were kept in the same experimental pen, where cows had access to free stalls with waterbeds (DCC Waterbeds, Advanced Comfort Technology Inc., Reedsburg, WI), which were bedded with wood shavings, TMR was provided ( 1 to $3 \times / d$ ) in roughage intake feed bins (Insentec B.V., Marknesse, the Netherlands), and milked on a set schedule ( 2 or $3 \times / d)$ using an automatic milking system (Lely A3 Next, Lely Industries N.V., Maassluis, the Netherlands) with no additional feed provided at the milking unit. Table 1 describes details of the studies used to create the database, including number of animals, parity distribution, and details of dietary composition. All diets fed were similar in ingredient composition, but varied in nutrient content and physical particle structure. Table 2 describes the average parity, DIM, and BW of cows during periods when data were collected in each study. Use of cows in each study was approved by the University of Guelph's Animal Care Committee; cows were managed according to the guidelines set forth by the Canadian Council on Animal Care (CCAC, 2009).

Behavior data, as summarized in Table 2, were collected similarly in all source studies. Dry matter intake and feeding behavior were recorded automatically by the roughage intake feed bins (Insentec B.V.), as validated by Chapinal et al. (2007). Data from the feed bins were used to calculate DMI $(\mathrm{kg} / \mathrm{d})$, feeding time $(\mathrm{min} / \mathrm{d})$, and feeding rate $(\mathrm{kg} / \mathrm{min})$. Meal criteria were individually calculated for each cow, as described by DeVries et al. (2003), and applied to the feeding data to calculate meal frequency (no./d), meal length (min/ meal), daily mealtime $(\mathrm{min} / \mathrm{d}$; daily mealtime includes feeding time as well as nonfeeding time within meals while cows had their head outside the feed bin), and meal size ( $\mathrm{kg}$ of $\mathrm{DM} / \mathrm{meal})$. Rumination behavior data were collected by automatic rumination detection devices (Lely Qwes-HR collars, Lely Industries N.V.), as validated by Schirmann et al. (2009).

Production data, as summarized in Table 2, were collected similarly in all source studies. Milk yield data were automatically recorded daily, at each milking, by an automated milking system (Lely A3 Next, Lely Industries N.V.). Milk samples were collected from each milking for either 3 d (Hart et al., 2013, 2014; DeVries and Chevaux, 2014) or 2 d (King et al., 2016a,b), during each experimental period using the Lely Shuttle Sampling Device (Lely Industries N.V.) and sent to a DHI testing laboratory (CanWest DHI, Guelph, Ontario, Canada) for analysis of milk fat and protein percentage using a near-infrared analyzer (FOSS System 4000 Infrared Transmission Analyzer, Foss, Hillerød, Denmark). The yield of $4 \% \mathrm{FCM}(\mathrm{kg} / \mathrm{d})$ was calculated $(\mathrm{NRC}, 2001)$ as $0.4 \times$ milk yield $(\mathrm{kg} / \mathrm{d})+15.0 \times$ fat yield $(\mathrm{kg} / \mathrm{d})$. Energy-corrected milk was calculated using the following equation: $\mathrm{ECM}=(0.327 \times \mathrm{kg}$ of milk $)$ $+(12.95 \times \mathrm{kg}$ of fat $)+(7.2 \times \mathrm{kg}$ of protein $)$ (Tyrrell and Reid, 1965).

Cows were individually exposed to either 2 or 3 treatments within the studies their data were sourced from. For the current analyses, the experimental unit was the cow-week observation, each of which was the average of daily data collected for a cow during 7-d data collection periods, per treatment, in each respective study. Data were averaged on a per-week basis to improve the accuracy of the estimate of the true mean for each predictor and outcome variable. Prior to analyses, all data were screened for normality using the UNIVARIATE procedure of SAS version 9.4 (SAS Institute Inc., Cary, NC).

Table 1. Cow and dietary characteristics ${ }^{1}$ for data used from 5 previous studies ${ }^{2}$

\begin{tabular}{|c|c|c|c|c|c|c|c|c|c|c|c|}
\hline Study $^{1}$ & Parity $^{3}$ & $\begin{array}{c}\text { DIM at start }{ }^{4} \\
(\text { mean } \pm \mathrm{SD})\end{array}$ & $\begin{array}{c}\text { Forage } \\
\text { content } \\
(\% \text { DM) }\end{array}$ & \multicolumn{4}{|c|}{ TMR nutrient composition } & \multicolumn{4}{|c|}{ Particle size distribution $^{5}(\%)$} \\
\hline 1 & $6 \mathrm{PP}$ and $6 \mathrm{MP}$ & $104 \pm 32$ & 52.4 & 50.4 & 17.1 & 31.7 & 1.60 & 12.6 & 46.5 & 31.9 & 9.0 \\
\hline 2 & $7 \mathrm{PP}$ and $5 \mathrm{MP}$ & $171 \pm 31$ & 64.0 & 48.9 & 16.7 & 33.0 & 1.70 & 16.7 & 44.6 & 31.5 & 7.1 \\
\hline 3 & $2 \mathrm{PP}$ and $10 \mathrm{MP}$ & $95 \pm 17$ & 57.7 & 54.7 & 17.9 & 34.4 & 1.66 & 7.2 & 45.7 & 31.9 & 15.3 \\
\hline 4 & $4 \mathrm{PP}$ and $8 \mathrm{MP}$ & $77 \pm 23$ & 60.3 & 55.8 & 16.7 & 30.8 & 1.65 & 1.8 & 45.0 & 37.0 & 16.2 \\
\hline
\end{tabular}

${ }^{1}$ All diets were TMR composed of corn silage, legume/grass haylage, high-moisture corn, grain supplement, and protein concentrate.

${ }^{2}$ Studies are as follows: (1) Hart et al., 2014; (2) Hart et al., 2013; (3) DeVries and Chevaux, 2014; (4) King et al., 2016a; and (5) King et al., $2016 \mathrm{~b}$.

${ }^{3} \mathrm{PP}=$ primiparous; $\mathrm{MP}=$ multiparous.

${ }^{4}$ Mean DIM at the start of each data collection period for each cow (cow-week) on each treatment within each respective study.

${ }^{5}$ Particle size of TMR as determined by Penn State Particle Separator, which has a 19-mm screen (long), 8-mm screen (medium), 1.18-mm screen (short), and a pan (fine). 
Table 2. Descriptive statistics (mean, SD, minimum, maximum) of production outcomes and explanatory variables included in the models $\left(n=132\right.$ cow-weeks $\left.{ }^{1}\right)$

\begin{tabular}{|c|c|c|c|c|}
\hline Item & Mean & SD & Minimum & Maximum \\
\hline \multicolumn{5}{|l|}{ Outcome variable } \\
\hline DMI $(\mathrm{kg} / \mathrm{d})$ & 27.0 & 3.1 & 21.1 & 35.8 \\
\hline \multicolumn{5}{|l|}{ Milk yield (kg/d) } \\
\hline Milk & 43.0 & 7.0 & 25.3 & 60.2 \\
\hline $4 \% \mathrm{FCM}$ & 40.1 & 6.8 & 24.4 & 56.4 \\
\hline ECM & 43.1 & 6.9 & 26.7 & 58.6 \\
\hline \multicolumn{5}{|l|}{ Milk composition (\%) } \\
\hline Fat & 3.60 & 0.49 & 2.07 & 5.20 \\
\hline Protein & 3.05 & 0.25 & 2.51 & 3.82 \\
\hline \multicolumn{5}{|l|}{ Milk component yield $(\mathrm{kg} / \mathrm{d})$} \\
\hline Fat & 1.53 & 0.30 & 0.81 & 2.34 \\
\hline Protein & 1.29 & 0.17 & 0.84 & 1.70 \\
\hline \multicolumn{5}{|l|}{ Explanatory variable } \\
\hline Parity & $1.8^{2}$ & 0.87 & 1 & 6 \\
\hline $\mathrm{DIM}^{3}$ & 108.4 & 42.7 & 35 & 232 \\
\hline BW (kg) & 654.6 & 71.4 & 481.0 & 809.7 \\
\hline Feeding time $(\min / \mathrm{d})$ & 230.4 & 35.5 & 99.4 & 312.8 \\
\hline Feeding rate $(\mathrm{kg}$ of $\mathrm{DMI} / \mathrm{min})$ & 0.13 & 0.029 & 0.08 & 0.27 \\
\hline Meal frequency (no./d) & 9.0 & 2.03 & 3.9 & 16.0 \\
\hline Meal size (kg of DM/meal) & 3.2 & 0.88 & 1.8 & 7.8 \\
\hline Meal length ( $\mathrm{min} / \mathrm{meal})$ & 29.6 & 7.6 & 16.2 & 52.9 \\
\hline Meal time $(\min / \mathrm{d})$ & 279.6 & 51.7 & 112.8 & 461.6 \\
\hline Rumination time (min/d) & 516.0 & 90.7 & 242.4 & 656.7 \\
\hline Rumination time (min $/ \mathrm{kg}$ of $\mathrm{DMI})$ & 19.3 & 3.8 & 9.4 & 29.2 \\
\hline
\end{tabular}

${ }^{1}$ Data collected across $7 \mathrm{~d} /$ cow $(2-4 \mathrm{~d} /$ cow for milk component data) and averaged to create weekly values.

${ }^{2}$ Parity distribution was 1 ( $\mathrm{n}=55$ cow-weeks), $2(\mathrm{n}=57$ cow-weeks), $3(\mathrm{n}=18$ cow-weeks), and 6 ( $\mathrm{n}=2$ cowweeks); parity was categorized as 1 (primiparous) and $2+$ (multiparous).

${ }^{3} \mathrm{DIM}=$ mean DIM of cows at the beginning of each data collection period (cow-week).

Mixed multivariable linear regression models were built to assess whether there were associations between behavioral (Table 2), cow level (parity, DIM, and BW; Table 2), and dietary predictors (forage level; nutrient content: $\mathrm{DM} \%, \mathrm{CP} \%, \mathrm{NDF} \%$, and $\mathrm{NE}_{\mathrm{L}}$; particle size distribution; Table 1) and production outcomes (Table 2). Models were constructed using the MIXED procedure of SAS (SAS Institute Inc.). Multiple observations per cow within each source study (i.e., different treatments) were accounted for in each model by including treatment in the repeated statement. Thus, the random effects were study and cow within treatment and study (subject of the repeated statement). Compound symmetry was selected as the covariance structure on the basis of best fit according to Schwarz's Bayesian information criterion. Degrees of freedom for fixed effects were estimated using the Kenward-Roger option in the MODEL statement.

All predictor variables hypothesized to be related to the outcome of interest were initially screened for unconditional associations in univariable analyses. Any predictor variables that were liberally associated with the outcome $(P<0.25)$ were considered for inclusion in the final model. Continuous variables were assessed for linearity with the outcome variables. If a variable was nonlinear, a quadratic term was constructed and tested in the model. If the quadratic terms were not significant, then logarithmic and square root transformations were tested. If none of the transformations appeared to improve linearity, the variable was categorized.

Spearman correlation coefficients were calculated for all predictor variables that were considered for inclusion in the multivariable model to detect issues of collinearity. Consequently, if the correlation coefficient was greater than $|0.8|$, then either the variable that made the most biological sense was used or that with the lower $P$-value. A confounding variable was defined as a nonintervening variable whose removal resulted in a $>25 \%$ change in the coefficients of significant variables in the final model. Predictor variables in each model were checked for interaction by including all biologically appropriate 2-way interaction terms into the model. Variables were retained in the final multivariable model if they were significant at $P \leq 0.05$ or tendencies at $0.05<P \leq 0.10$, if they acted as a confounder, or were part of a significant interaction term.

Dry matter intake varied across cows in the study data sets (Table 2). When controlling for parity and BW, DMI was positively associated with feeding time, and tended to be associated with rumination time and meal frequency (Table 3). Specifically, for every hour increase in feeding time per day, DMI is predicted to in- 
crease by $0.96 \mathrm{~kg} / \mathrm{d}$ (Table 3 ); this equates to a predicted $3.4 \mathrm{~kg} / \mathrm{d}$ difference in DMI between those cows in our data set with the least and greatest feeding time (Table 2 ). For every extra meal per day, DMI is predicted to tend to increase by $0.19 \mathrm{~kg} / \mathrm{d}$ (Table 3 ); this equates to a predicted $2.3 \mathrm{~kg} / \mathrm{d}$ difference in DMI between those cows with the least and greatest meal frequency (Table 2 ). The associations with feeding time and meal frequency are not unexpected, as any alteration in DMI must be accompanied by a concomitant change in feeding behavior (Nielsen, 1999). Thus, cows in our data set were achieving higher DMI through spending more time feeding, distributed among a greater frequency of meals, rather than only consuming their feed at a faster rate, in larger meals. The association of DMI with feeding time is consistent with research conducted by Huzzey et al. (2007), who also identified positive association between feeding time and DMI while studying the risk factors associated with metritis in dairy cattle. The tendency for an association of DMI and meal frequency is less consistent with the literature. Dado and Allen (1994) reported a positive correlation between DMI of TMR and meal frequency; however, the correlation was even stronger for meal size in that study. Similarly, Beauchemin et al. (2002) reported that those cows consuming the greatest amount of feed ate their TMR in fewer, but larger meals each day. More recently Azizi et al. (2009) found highly positive correlations between meal duration, daily mealtime, and DMI in the higher-producing cows observed in their study. It should be noted that production levels varied in these studies (Beauchemin et al., 2002: $18.2 \mathrm{~kg} / \mathrm{d}$ of DMI and $27.2 \mathrm{~kg} / \mathrm{d}$ of milk yield; Dado and Allen, 1994: 22.4 $\mathrm{kg} / \mathrm{d}$ of DMI and $33.1 \mathrm{~kg} / \mathrm{d}$ of milk yield; and Azizi et al., 2009: $21.3 \mathrm{~kg} / \mathrm{d}$ of DMI and $39.4 \mathrm{~kg} / \mathrm{d}$ of milk yield), and were all lower than the current study (27 $\mathrm{kg} / \mathrm{d}$ of DMI and $43.0 \mathrm{~kg} / \mathrm{d}$ of milk yield). This indicates that at higher production levels, cows may not necessarily be able to increase DMI by simply changing the size of meals and rate at which feed is consumed within a meal, but rather need to consume more meals over a longer period of time within the day. It is also possible that these differences between studies may be related to differences in diet composition. It should be noted, however, that the range of dietary forage content was similar across these studies to those used for the current analysis, with the exception of Beauchemin et al. (2002) who fed a lower forage (40\% of DM) diet in addition to more moderate levels of forage (50-60\% of DM). In that study, meal frequency and size did not vary with dietary forage content. In the current study, both larger meal size and faster feeding rate were also associated with DMI at a univariable level; however, given the high correlation between these variables and meal frequency and feeding time, respectively, they could not be included in the same predictive model of DMI. Meal frequency and feeding time were chosen for multivariable modeling given that they accounted for more variability in DMI at a univariable level. Further, previous associations of measures of feeding behavior with DMI have not accounted for differences in cowlevel factors (such as parity and BW), as done in the current study (Table 3).

Feeding time was also associated with milk yield, and meal frequency tended to be associated with milk yield (Table 3). Specifically, for every hour increase in feeding time per day, milk yield is predicted to increase by $1.74 \mathrm{~kg} / \mathrm{d}$ (Table 3 ); this equates to a predicted 6.2 $\mathrm{kg} / \mathrm{d}$ difference in milk yield between those cows in our data set with the least and greatest feeding time (Table 2). For every extra meal per day, milk yield is predicted to tend to increase by $0.3 \mathrm{~kg} / \mathrm{d}$ (Table 3 ); this equates to a predicted $3.6 \mathrm{~kg} / \mathrm{d}$ difference in milk yield between those cows with the least and greatest meal frequency (Table 2). Similar associations with 4\% FCM and ECM were also observed (data not shown). These associations between feeding behavior and milk yield are likely explained by the association of these variables with DMI.

The association of rumination time with DMI (Table 3 ) is also not consistent in the literature. In research with dry cows, Schirmann et al. (2012) demonstrated no association of rumination time with DMI. Alternatively, Clément et al. (2014) recently found that rumination time was a significant, but smaller contributor, in a DMI prediction model; their model predicted increases of $0.031 \mathrm{~kg}$ of $\mathrm{DMI} / \mathrm{h}$ of rumination time. This is in contrast to the present model that predicts an increase in $0.2 \mathrm{~kg}$ of $\mathrm{DMI} / \mathrm{h}$ of rumination time (Table 3). The difference between studies is likely due to Clément et al. (2014) also using milk yield (FCM) in their predictive model; given that greater milk yield is inherently resultant of increased DMI, the FCM yield would be expected to account for much of the variance in their model. It should be noted, however, that the magnitude of the observed association in the present study is still very limited, as the current model (Table 3 ) only predicts a $1.4 \mathrm{~kg} / \mathrm{d}$ difference in DMI between those cows with the least and greatest rumination time (Table 2). It is long established that rumination activity of cattle is correlated with total dietary NDF intake (Dado and Allen, 1995; Nørgaard et al., 2010). In the present analysis, dietary NDF concentration was similar across study data sets (Table 1), and thus it is not surprising that rumination time would increase with DMI level, and thus total NDF intake. One could also hypothesize that greater rumination may also contribute to greater DMI, as rumination may contribute to more effective 


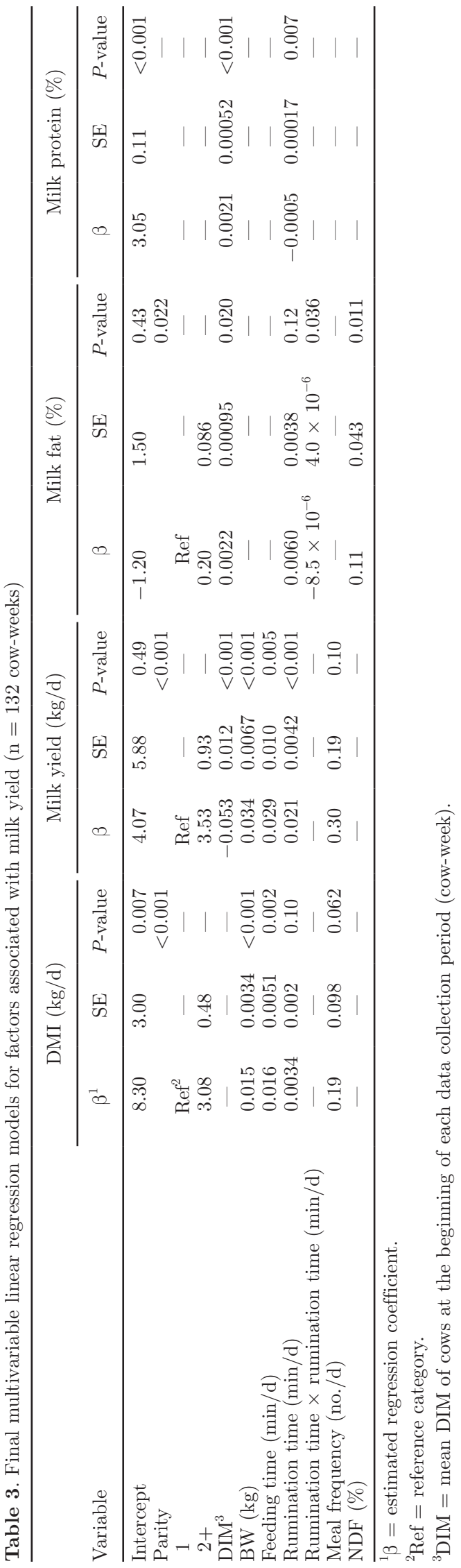

particle size reduction, improved digestibility, and faster passage rate (Aikman et al., 2008).

Greater rumination time was also associated with greater milk yield in the present study (Table 3). Specifically, for every hour increase in rumination time per day, milk yield is predicted to increase by $1.26 \mathrm{~kg} / \mathrm{d}$ (Table 3 ); this equates to a predicted $8.7 \mathrm{~kg} / \mathrm{d}$ difference in milk yield between those cows in our data set with the least and greatest rumination time (Table 2). Dado and Allen (1994) similarly found that higher-producing cows tended to have fewer ruminating bouts per day, but each bout was longer, resulting in a tendency for these cows to ruminate longer each day. Interestingly, those researchers also demonstrated that the increased rumination was proportional to increases in DMI, as cows spent less time ruminating per unit of DMI as intake and production increased (Dado and Allen, 1994). In the present analysis, total rumination time, and not rumination time per unit of DMI, was associated with milk yield. This suggests that, when accounting for cow-level factors, those cows with greater DMI, were then ruminating more, and also producing more milk as result of that greater nutrient intake.

Milk fat content and yield data of study cows are presented in Table 2. When controlling for parity, DIM, and dietary NDF concentration, milk fat content was associated with rumination time quadratically (Figure 1; Table 3). Two explanations are possible for this nonlinear association of milk fat content with rumination time. Evidence indicates that greater milk yield has a dilution effect on milk components (Chalupa and Sniffen, 2000). Thus, for those cows that were ruminating the most, milk fat may have been lower because they were also the highest production cows. This would then explain why milk protein content was negatively associated with rumination time (Table 3). It could also be that those high-production cows were increasing their rumination time to compensate for low ruminal $\mathrm{pH}$. Low ruminal $\mathrm{pH}$ is known to be associated with milk fat depression (Griinari et al., 1998; AlZahal et al., 2010). Further, it has also been shown that cows that experienced depressed rumen $\mathrm{pH}$ will increase their time devoted to rumination activity (DeVries et al., 2009) to increase buffering activity in the rumen.

When controlling for parity and BW, milk fat yield was positively associated with meal frequency $(0.018$ $\pm 0.0092 \mathrm{~kg}$ of fat $/$ meal; $P=0.05)$, whereas protein yield was positively associated with rumination time $(0.00033 \pm 0.00013 \mathrm{~kg}$ of protein $/ \mathrm{min}$ rumination; $P$ $=0.01)$ and feeding time $(0.00084 \pm 0.00029 \mathrm{~kg}$ of protein $/ \mathrm{min}$ of feeding time; $P=0.005)$. These associations are explained by the previously described associations of these behavioral predictor variables with total milk yield. 


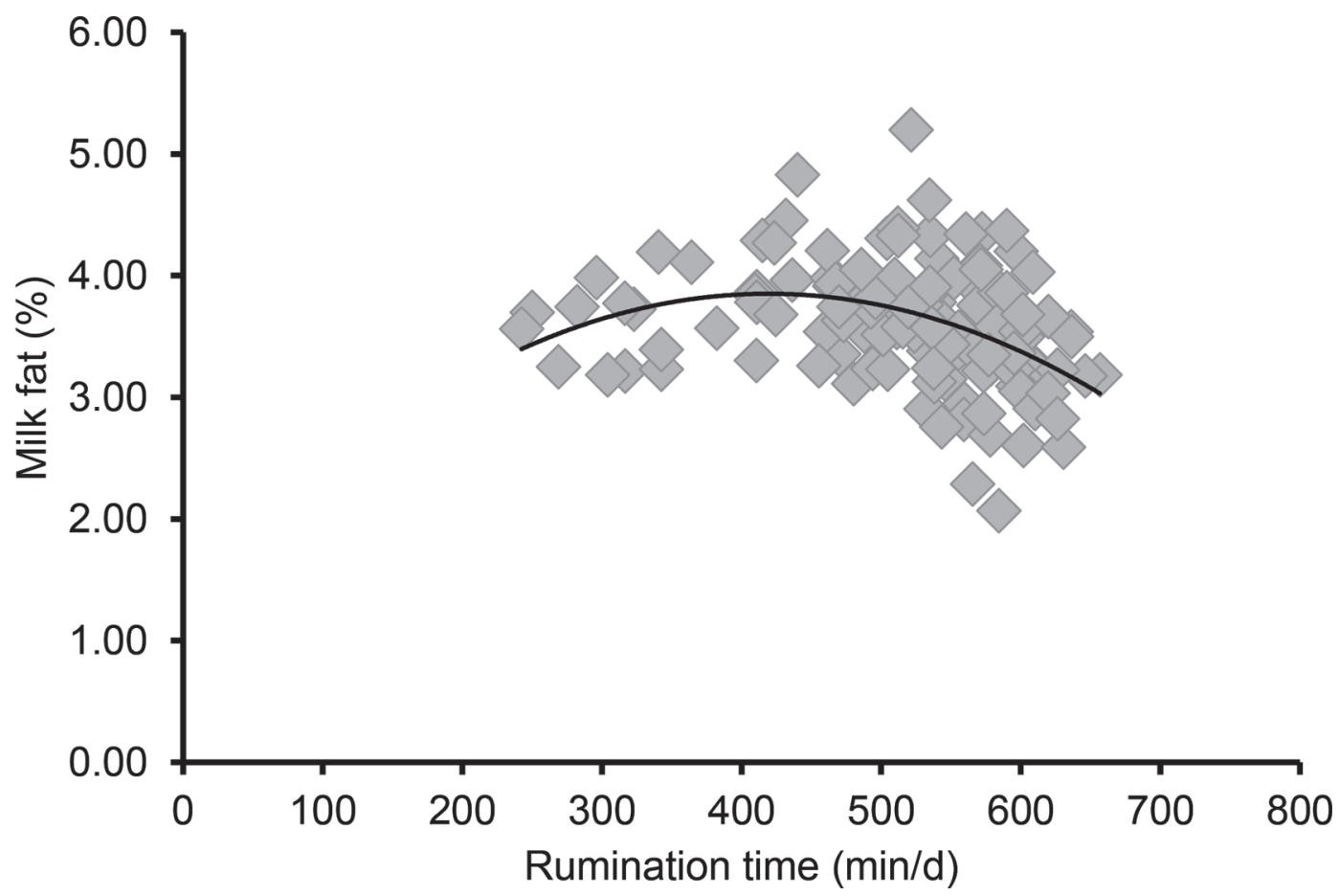

Figure 1. Univariable association of rumination time ( $\mathrm{min} / \mathrm{d})$ with milk fat content $(\% ; \mathrm{n}=132$ cow-weeks).

Overall, the results of this multi-study analysis identify associations between feeding behavior and production outcomes in dairy cows. Factors found to be associated with greater DMI and production include rumination time, meal frequency, and feeding time. These results suggest that nutritional, management, and housing factors that improve time spent feeding, in more frequent meals, and time spent ruminating may have a positive effect on milk yield and component production.

\section{ACKNOWLEDGMENTS}

Thank you to the research and barn staff at the University of Guelph, Kemptville Campus, Dairy Education and Innovation Center (Kemptville, ON, Canada) for their contributions to the data collected in the summarized studies. This project was financially supported by a Natural Sciences and Engineering Research Council of Canada (NSERC; Ottawa, ON, Canada) Discovery Grant (T. J. DeVries).

\section{REFERENCES}

Aikman, P., C. Reynolds, and D. Beever. 2008. Diet digestibility, rate of passage, and eating and rumination behavior of Jersey and Holstein cows. J. Dairy Sci. 91:1103-1114.

Allen, M. S. 1997. Relationship between fermentation acid production in the rumen and the requirement for physically effective fiber. J. Dairy Sci. 80:1447-1462.
AlZahal, O., M. M. Or-Rashid, S. L. Greenwood, and B. W. McBride. 2010. Effect of subacute ruminal acidosis on milk fat concentration, yield and fatty acid profile of dairy cows receiving soybean oil. J. Dairy Res. 77:376-384.

Azizi, O., O. Kaufmann, and L. Hasselmann. 2009. Relationship between feeding behavior and feed intake of dairy cows depending on their parity and milk yield. J. Dairy Sci. 122:156-161.

Beauchemin, K. A., M. Maekawa, and D. A. Christensen. 2002. Effect of diet and parity on meal patterns of lactating dairy cows. Can. J. Anim. Sci. 82:215-223.

CCAC. 2009. Guidelines on: The care and use of farm animals in research, teaching and testing. Canadian Council on Animal Care, Ottawa, ON, Canada.

Chalupa, W., and C. J. Sniffen. 2000. Balancing rations for milk components. Adv. Dairy Technol. 12:27-42.

Chapinal, N., D. M. Veira, D. M. Weary, and M. A. G. von Keyserlingk. 2007. Validation of a system for monitoring individual feeding and drinking behavior and intake in group housed cattle. J. Dairy Sci. 90:5732-5736.

Clément, P., R. Guatteo, L. Delaby, B. Rouillé, A. Chanvallon, J. M. Philipot, and N. Bareille. 2014. Short communication: Added value of rumination time for the prediction of dry matter intake in lactating dairy cows. J. Dairy Sci. 97:6531-6535.

Dado, R. G., and M. S. Allen. 1994. Variation in and relationships among feeding, chewing, and drinking variables for lactating dairy cows. J. Dairy Sci. 77:132-144.

Dado, R. G., and M. S. Allen. 1995. Intake limitations, feeding behavior, and rumen function of cows challenged with rumen fill from dietary fiber or inert bulk. J. Dairy Sci. 78:118-133.

DeVries, T. J., K. A. Beauchemin, F. Dohme, and K. S. SchwartzkopfGenswein. 2009. Repeated ruminal acidosis challenges in lactating dairy cows at high and low risk for developing acidosis: Feeding, ruminating, and lying behavior. J. Dairy Sci. 92:5067-5078.

DeVries, T. J., and E. Chevaux. 2014. Modification of the feeding behavior of dairy cows through live yeast supplementation. J. Dairy Sci. 97:6499-6510. 
DeVries, T. J., M. A. G. von Keyserlingk, D. M. Weary, and K. A. Beauchemin. 2003. Measuring the feeding behavior of lactating dairy cows in early to peak lactation. J. Dairy Sci. 86:3354-3361.

Grant, R. J., and J. L. Albright. 1995. Feeding behavior and management factors during the transition period in dairy cattle. J. Anim. Sci. 73:2791-2803.

Griinari, J. M., D. A. Dwyer, M. A. McGuire, D. E. Bauman, D. L. Palmquist, and K. V. V. Nurmela. 1998. Trans octadecenoic acids and milk fat depression in lactating dairy cows. J. Dairy Sci. 81:1251-1261.

Hart, K. D., B. W. McBride, T. F. Duffield, and T. J. DeVries. 2013 Effect of milking frequency on the behavior and productivity of lactating dairy cows. J. Dairy Sci. 96:6973-6985.

Hart, K. D., B. W. McBride, T. F. Duffield, and T. J. DeVries. 2014 Effect of frequency of feed delivery on the behavior and productivity of lactating dairy cows. J. Dairy Sci. 97:1713-1724.

Huzzey, J. M., D. M. Veira, D. M. Weary, and M. A. G. von Keyserlingk. 2007. Prepartum behavior and DMI identify dairy cows at risk for metritis. J. Dairy Sci. 90:3220-3233.

King, M. T. M., R. E. Crossley, and T. J. DeVries. 2016a. Impact of timing of feed delivery on the behavior and productivity of dairy cows. J. Dairy Sci. 99:1471-1482.

King, M. T. M., R. E. Crossley, and T. J. DeVries. 2016b. Synchronization of dairy cows does not limit the behavioral response to treatment in mixed treatment experimental designs. Front. Vet. Sci. 3:98. https://doi.org/10.3389/fvets.2016.00098.
Krause, K. M., and G. Oetzel. 2006. Understanding and preventing subacute ruminal acidosis in dairy herds: A review. Anim. Feed Sci. Technol. 126:215-236.

NRC. 2001. Nutrient Requirements of Dairy Cattle. 7th rev. ed. Natl. Acad. Sci., Washington, DC.

Nielsen, B. L. 1999. On the interpretation of feeding behaviour measures and the use of feeding rate as an indicator of social restraint. Appl. Anim. Behav. Sci. 63:79-91.

Nørgaard, P., E. Nadeau, and A. T. Randby. 2010. A new Nordic evaluation system for diets fed to dairy cows: A meta analysis. Pages 112-120 in Modelling nutrient digestion and utilisation in farm animals. D. Sauvant, J. Van Miligen, P. Faverdin, and N. Friggens, ed. Wageningen Academic Publishers, Wageningen, the Netherlands.

Schirmann, K., N. Chapinal, D. M. Weary, W. Heuwieser, and M. A. G. von Keyserlingk. 2012. Rumination and its relationship to feeding and lying behavior in Holstein dairy cows. J. Dairy Sci 95:3212-3217.

Schirmann, K., M. A. G. von Keyserlingk, D. M. Weary, D. M. Veira, and W. Heuwieser. 2009. Validation of a system for monitoring rumination in dairy cows. J. Dairy Sci. 92:6052-6055.

Tyrrell, H. F., and J. T. Reid. 1965. Prediction of the energy value of cow's milk. J. Dairy Sci. 48:1215-1223.

Veerkamp, R. F. 1998. Selection for economic efficiency of dairy cattle using information on live weight and feed intake: A review. J. Dairy Sci. 81:1109-1119 